\title{
THE CONSTITUTIONALITY OF THE FUGITIVE SLAVE ACTS
}

\author{
Aluen Johnson \\ Yale University
}

Time has done much to assuage the passions aroused by the controversy over slavery in the United States. Patient investigation North and South is taking the place of heated denunciation and defence; many misapprehensions have been cleared away; yet some unfortunate errors persist even in the writings of candid historians. Of the measures passed by Congress in the heat of the controversy, none has been so persistently misrepresented as the Fugitive Slave Act of I85o. By common consent historians north of Mason and Dixon's line have taken over the contemporary opinion of men and women who held with Charles Sumner that the act was "most cruel, unchristian, devilish, setting at naught the best principles of the Constitution and the very laws of God." 1 James Schouler pronounces the act "inhuman and scarcely within the full shelter of the Federal constitution."2 The usually fair-minded Rhodes declares it "one of the most assailable laws ever passed by the Congress of the United States," the mere statement of its provisions condemning it as a reproach to Christian America. ${ }^{3}$ Yet the mere statement which $\mathrm{Mr}$. Rhodes gives of its provisions proves quites clearly that he understands neither the Act of 1850 nor the earlier measure to which it was supplementary. It is the purpose of this paper to set the Act of 1850 against its appropriate historical background and to test its constitutionality, without reference to the wisdom or expediency of its enactment.

The paragraph in the second section of the fourth article of the Constitution relating to the rendition of fugitives from service or labor was adopted unanimously, and apparently without discussion, by the Federal Convention. ${ }^{4}$ In its final form it read:

"No Person held to Service or Labour in one State, under the Laws thereof, escaping into another, shall, in Consequence of any law or Regulation therein, be discharged from such Service or Labour, but shall be delivered up on Claim of the Party to whom such Service or Labour may be due."

Of this paragraph Judge Story remarked in his opinion in the Prigg case: "it cannot be doubted that it constituted a fundamental article,

\footnotetext{
2 Sumner, Orations and Speeches (1850) 400.

$=5$ Schouler, History of the United States of America (I89I) 205-206.

${ }^{3}$ I Rhodes, History of the United States from the Compromise of I850 (I893) 185-186.

'2 Farrand, Records of the Federal Convention (I9Ir) 446.
} 
without the adoption of which the Union could not have been formed." ${ }_{5}$ This was a favorite thesis with the judiciary of his day, but it is not supported by any positive historical evidence. Addressing the ratifying convention in Virginia, June 17,1788 , Madison discussed the paragraph briefly but attributed to it no particular sanctity above other parts of the Constitution. He contented himself with pointing out that it offered a better security to slave-owners than they enjoyed under the Articles ot Confederation, for "at present," said he, "if any slave elopes to any of those states where slaves are free, he becomes emancipated by their laws." "This clause," Madison added, "was expressly inserted to enable owners of slaves to reclaim them." Nor is there anything in the proceedings of other ratifying conventions which supports Judge Story's contention.

One possible inference may be drawn from Madison's brief comment. $\mathrm{He}$ at least seemed to believe that the constitutional provision for the delivery of fugitive slaves would. be adequate to its purpose. At all events, he does not intimate that more than the constitutional obligation would be needed to produce faithful observance. Nothing in the history of the Confederation justified this expectation of state comity, it is true, and no one knew better than Madison that the states had not outgrown their old habits. If such was Madison's expectation, it was soon disappointed, for the provisions of the Constitution proved neither self-executory nor adequate. ${ }^{\top}$

In June, I79I, Governor Thomas Mifflin of Pennsylvania made demand upon Governol Randolph of Virginia for the surrender of three men who were charged wrh having forcibly seized a negro in Washington, Pennsylvania, and taken himi into Virginia with the intention of selling him as a slave. This act of violence was declared by Governor Mifflin to be "contrary to the Act of the General Assembly." Governor Randolph declined to comply on three general grounds : first, because the alleged offence did not seem to fall within the category of crimes mentioned in article IV, section 2 , of the Constitution ${ }^{8}$; secondly, because in any case the offence was not of such character as to give Pennsylvania exclusive jurisdiction; thirdly, because the Constitution

${ }^{5}$ Prigg v. Pennsylvania (1842, U. S.) 16 Pet. 539, 6rx. Justice Tilghman said in Wright v. Deacon" (I8rg, Pa.) 5 Serg. \& R. 62, 63: "It is well known that our southern brethren would not have consented to become parties to a constitution ...., unless their property in slaves had been secured." Judge McLean said in Giltner v. Gorham (1848, C. C. D. Ill.) 4 McLean, 402, 425: "The clause was deemed so important, that, as a matter of history, we know. the Constitution could not have been adopted without it."

${ }^{3} 3$ Farrand, op. cit., 325.

'It may be argued, of course, that here, as elsewhere, the framers of the Constitution may have preferred to leave Congress to supply the machinery of administration rather than overload the document with details.

s "Treason, felony, or other crime" is the statement of the second paragraph. 
was silent as to the mode in which fugitives are to be apprehended and removed, leaving to the state authorities only the use of force, which was contrary to the State Constitution and laws.

Governor Mifflin referred the case to President Washington, who in turn sought the opinion of the Attorney-General, Edmund Randolph, and finally laid the correspondence before Congress in a special message. The Attorney-General sided with the executive of his native state to this extent, that he was fully justified in refusing delivery of the fugitives until the Governor of Pennsylvania had furnished satisfactory evidence that the alleged offenders had fled out of Pennsylvania and had been found in Virginia. It would have been "more precise," too, for the Governor of Pennsylvania to have transmitted an authenticated copy of the law declaring the offence. On the other hand, the Attorney-General was of the opinion-the Governor of Virginia to the contrary, notwithstanding - that exclusive jurisdiction of the offence did belong to Pennsylvania, and that the surrender of the fugitives (once satisfactory evidence was supplied) was a federal duty and implied the "right of using all incidental means in order to discharge it."

"I will not inquire here," continued the Attorney General, "how far these incidental means, if opposed to the constitution and laws of Virginia, ought, notwithstanding, to be exercised; because.... [the offenders] may be surrendered without calling upon any public officer of that State. Private persons may be employed, and clothed with a special authority. The Attorney-General agrees that a law of the United States might so ordain; and wherein does a genuine distinction consist between a power deducible from the constitution, as incidental to a duty imposed by that constitution, and a power given by Congress as auxiliary to the execution of such a duty?"9

It was probably the considerations suggested by this controversy which moved Congress to enact the law of I793. No controversy over the delivery of fugitives from labor seems to have been brought to the attention of Congress before this date; yet both objects were brought within the purview of this Act. ${ }^{10}$ Congress anticipated, it would seem, the same difficulties in the way of the delivery of fugitive slaves as of fugitives from justice. But was the owner of a slave placed in a similar predicament in securing the delivery of his property? Could he not seize his property wherever found under authority of the Constitution, and without the aid of either federal or state officials. No less an authority than Joseph Story held that "under and in virtue of the Constitution, the owner of a slave is clothed with entire authority, in every State in the Union, to seize and recapture his slave, wherever he can do it without any breach of the peace, or any illegal violence."11

\footnotetext{
- 20 Amer. State Papers, Misc. I, 42.

${ }^{10}$ An Act respecting fugitives from justice, and persons escaping from the service of their masters. February 12, 1793 (I Stat. at L. 302).

"Prigg v. Pennsylvania (1842, U. S.) I6 Pet. 539, 613.
} 
But it was precisely the possibility of breach of the peace and illegal violence which made legislation by Congress seem desirable, if not imperative. As counsel in the case of Prigg $v$. Pennsylvania, fifty years later, remarked, ${ }^{12}$ free negroes might have been kidnapped at will, and rival claimants to the same fugitive would have had to settle their claims by force, had Congress not prescribed a procedure in the delivery of fugitives from service.

The Act passed by Congress in I793, then, had a two-fold purpose: first, to facilitate the extradition of fugitives from justice; and secondly, to assist the owners of slaves to recover their property without recourse to violence, and without breach of the peace. The first sections, accordingly, provide that upon demand of the State or Territory from which an alleged criminal has fled, the executive of a - State or Territory to which the fugitive has escaped shall cause his arrest; and shall deliver him to the agent appointed to receive him. With the demand shall be presented a copy of an indictment found against the fugitive from justice or an affidavit charging that he has committed treason, felony, or other crime, duly certified by the Governor of the State or Territory from which he has fled. The agent receiving the fugitive shall then be empowered to transport the fugitive to the State or Territory from which he has fled and any attempt at molestation is made punishable by fine and imprisonment. The third and fourth sections authorize a person to whom service or labor is due, or his agent, to seize the fugitive in any State or Territory to which he may have fled; to take him before any federal judge in such State or Territory, or "before any magistrate of a county, city, or town corporate;" and to offer proof by oral testimony or by affidavit certified by a magistrate of the State or Territory from which he has come, that the fugitive owes service or labor to the claimant. If satisfied by the proof the judge or magistrate shall issue a certificate of the facts which shall be sufficient warrant for removing the fugitive to the State or Territory from which he has fled. Any attempt to obstruct the claimant in seizing his property or to rescue the fugitive or to conceal him, is made punishable by fine.

The coupling of these two objects in the same act would seem to indicate that the framers conceived of the rendition of both kinds of fugitives as a process of extradition. In the first instance, the extraditional process is carried out by state agents; in the second, by the claimant, with the aid of federal or local officers. The attitude of mind of those who legislated in I793 was largely determined by the habits formed under the Confederation. A more perfect union had been formed, it is true, but it was still a union of states with large residuary powers and it was a union inter pares. There is abundant evidence

${ }^{12}$ Ibid. 577 . 
that the members of the Senate long continued to think of themselves as plenipotentiaries from quasi-independent states. Between these selfgoverning republics many of the forms and much of the spirit of international intercourse still obtained. The provisions of the Constitution for the extradition of fugitives from justice and labor and the act of I793 simply gave a definite expression to what had hitherto been a sort of international comity. Nothing was further from the thoughts of Congress than to create a national police charged under a federal statute with the duty of apprehending fugitives from justice and labor. So far as possible existing state agencies were to be employed in the process of extradition.

In actual operation the latter sections of the Act of 1793 were found to contain ambiguities and to encounter practical difficulties. Had Congress authority to employ state and local officers for extraditional purposes under article IV, section 2, of the Constitution? Had Congress authority to legislate at all in the premises? Such authority is nowhere expressly conferred in the Constitution; and if conferred at all, it must be by implication. From what substantive grant of power, then? Other embarrassing questions of competence arose. Could a state, in the exercise of its police power for the protection of the public, in effect, throw obstacles in the way of the apprehension of fugitives from service and labor? Could a state forbid its magistrates to perform the federal services imposed by the act? Could a state magistrate, in default of state law, of his own volition refuse to perform obligations laid upon him by the Act of 1793 ?

The first part of the Act of I793, affecting the extradition of fugitives from justice, contained no such ambiguities and gave occasion for few difficulties in practical operation. - It still stands as part of the law of the land. No one questions its constitutionality either on the ground that it leaves the fugitive from justice without the right to trial in the state to which he has fled, ${ }^{13}$ or on the ground that he is denied the

${ }^{13}$ "The person demanded has no constitutional right to be heard before the Governor." See Roberts v. Reilly (I885) II6 U. S. 80, 6 Sup. Ct. 29I. But it is generally agreed that the Governor may inquire into the sufficiency of the affidavit or indictment, to ascertain whether it charges the alleged fugitive from justice with a crime according to the laws of the State demanding his extradition. The Governor may also take steps to assure himself of the identity of the person apprehended with the person demanded as a fugitive from justice. The first of these inquiries is a question of law and judicial in its nature: it may be instituted by an application for a discharge upon a writ of habeas corpus. How far the second matter-the identity of the prisoner-may be reviewed judicially is still a moot point. See I Bailey, Jurisdiction ( 1899 ) sec. 388 . In any case, the question of guilt or innocence is not a proper subject of inquiry, in the State where the fugitive is apprehended, but must be determined by the tribunals of the State where the crime is alleged to have been committed. Ibid. 399. See also People v. Brady (I874) 56 N. Y. 182; People v. Donohue (1881) 84 N. Y. 438; Kingsbury's Case (1870) I06 Mass. 223. 
writ of habeas corpus. ${ }^{14}$ Keen dissatisfaction with the Statute so far as fugitive slaves were concerned was soon voiced by those States which lay on the confines of free soil. Losses of slaves were sufficiently numerous to move Maryland to appeal to Congress in I8I7 for a new law. The burden of complaint was that Pennsylvania had enacted laws against kidnapping which operated so as to prevent the seizure and recovery of fugitive slaves. A critical moment arrived in the history of the Act of 1793 , when, in I842, the constitutionality of one of these state acts was called in question in the Supreme Court of the United States.

The essential facts in the famous case of Prigg $v$. Pennsylvania ${ }^{15}$ may be stated very briefly. Prigg was the agent of Margaret Ashmore, a citizen of Maryland, who claimed the services of a negro woman who had escaped into Pennsylvania. He had entered the State, had caused the negro woman to be apprehended by a state constable acting under warrant of a magistrate of Pennsylvania, and had then presented the fugitive before the magistrate for a certificate authorizing him to remove her to Maryland. Upon the refusal of the magistrate to take further cognizance of the case, Prigg then carried the negro woman and her children across the State line and delivered them into the custody of Margaret Ashmore. For this action he was indicted and convicted of felony under a Pennsylvania statute of 1826 . By agreement between Maryland-which State had undertaken the defence for Prigg - and Pennsylvania, the case was then carried on writ of error from the Supreme Court of Pennsylvania to the Supreme Court of the United States.

The judgment of the Supreme Court, delivered by Mr. Justice Story and sustained by all the seven justices present, declared the Act of Pennsylvania unconstitutional and void and reversed the judgment of the court of Pennsylvania. Five of the seven justices affirmed the power of Congress to legislate in the premise; one denied the power; and one declined to consider the question. Not all of the five, again, seem to have agreed with the reasoning by which Mr. Justice Story defended the power of Congress; and many differed sharply from his interpretation of the obligations of state officials.

Addressing himself first to the question of the competence of Congress to legislate on the subject, Justice Story took the position that the second section of the fourth article of the Constitution constituted "a fundamental article without the adoption of which the Union could not have been formed." Had the Constitution not contained this article, every non-slave-holding State would have been at liberty to declare all runaway slaves free within its limits. But with this provision, the Constitution contains "a positive unqualified right" on

${ }^{14}$ United States v. Booth (1858, U. S.) 2I How. 506; In re Tarble (I87x, U. S.) I3 Wall. 397.

${ }^{15}$ ( 8442, U. S.) I6 Pet. 539. 
the part of the owner of the slave, which no State law or regulation can in any way qualify, regulate, control, or restrain." The owner's right to his property continues in the State to which the slave has fled, and he is therefore clothed with entire authority to seize and capture his slave "wherever he can do it without any breach of the peace, or any illegal violence." "In this sense, and to this extent this clause of the Constitution may properly be said to execute itself." But the Constitution does not stop with the mere recognition of a right, which circumstances may render void, but contains a clause, which implies at once a guaranty and a duty: "But he shall be delivered up on claim of the party to whom such service or labor may be due." "Now a claim," said Story, "is a demand of some matter as a right made by one person upon another, to do or to forbear to do some act or thing as a matter of duty." To present the claim and to secure the delivery, some legislation is necessary. If then the Constitution guarantees the right and requires the delivery of a slave on claim of the owner, clearly "the national government is clothed with the appropriate authority and functions to enforce it."18 Not content with this deduction of general authority, Story points out further that a claim to property must be made against some other person and thus implies a controversy between parties-one of those cases, in short, which may arise under the Constitution and to which the judicial power extends. ${ }^{17}$ Congress may, therefore, without question, prescribe the mode in which the judicial power shall function.

Justice Wayne, however, who in general supports Story, declared flatly ${ }^{18}$ :

"The case of a fugitive slave is not like that of a contest for other property, to be determined between two claimants by the remedy given by the tribunals of the state where the property may be. It is not a controversy between two persons claiming the right to a thing, but the assertion by one person of a right of property in another, to be determined.upon principles peculiar to such relation."

\footnotetext{
${ }^{20}$ Story added further: ". . . . the national government, in the absence of all positive provisions to the contrary, is bound, through its own proper departments, legislative, judicial, or executive, as the case may require, to carry into effect all the rights and duties imposed upon it by the Constitution." (I6 Pet. 6I6.) And again: "The end being required, it has been deemed a just and necessary implication, that the means to accomplish it are given also; ..." (ibid. 619). By way of example Story points out that no one has ever questioned the power of Congress to apportion representation, though the power is nowhere expressly conferred and is usually derived from the power to provide for an enumeration of the population. But here, it may be remarked, the general grant is specifically to Congress. The second section of article IV-if it confers any power at allcertainly does not designate the department of government which shall exercise it

${ }^{17}$ It should be noted in passing that Story did not make clear who the parties to the controversy were. The claimant might conceivably be one of the two, but who was the other-the official who was to make the delivery?

${ }^{18}$ Prigg v. Pennsylvania, supra, at p. 646 .
} 
And so far as the other justices are concerned, the power of Congress to legislate was assumed to flow from the implied obligation of article IV, section 2.

Again, in discussing the question whether the power of legislation on the matter of fugitive slaves was exclusively in the national government or concurrent in the states, Story reiterated that the right to retake fugitive slaves, the duty to deliver them, and the corresponding power in Congress to use appropriate means to enforce the right and duty were derived wholly from the Constitution. Before the adoption of the Constitution the return of the fugitive was a matter of comity between the states, not a matter of moral or political obligation. The Constitution created "a new and positive right, independent of comity, confined to no territorial limits and bounded by no State institutions or policy." It would be absurd, therefore, to suppose that the Constitution intended to leave the national government dependent upon the states for the execution of its obligation. The very nature of the power, indeed, is such-continued Story-that it must be controlled by one and the same will, in order that it may operate uniformly. ${ }^{19}$

In only one particular did Story express any doubt about the constitutionality of the Act of 1793 . He intimated that the part which conferred a,uthority upon state magistrates was not free from uncertainty.

"As to the authority so conferred upon state magistrates, while a difference of opinion has existed, and may exist still on the point, in different states, whether state magistrates are bound to act under it; none is entertained by this Court that state magistrates may, if they choose, exercise that authority, unless prohibited by state legislation. ${ }^{20}$

Communities in which the current of anti-slavery sentiment ran strong, promptly availed themselves of this loophole in the Act of I793. A crop of so-called Personal Liberty Acts sprang up, of which the Vermont Act of November I, I843 is a fair sample. ${ }^{21}$ It forbade any

\footnotetext{
${ }^{10}$ Story quoted with approval the dictum of Marshall in Sturgis v. Crozuninshield (1819, U. S.) 4 Wheat 122, 193; "Whenever the terms in which a power is granted to Congress, or the nature of the power, require that it should be exercised exclusively by Congress, the subject is as completely taken from the State Legislatures, as if they had been forbidden to act on it." This denial of concurrent jurisdiction was not supported by the entire bench. Chief Justice Taney, for example, held that, while no State might pass any law in conflict to that of Congress, the States still have the right to aid in the enforcement of the constitutional obligation.

${ }^{20}$ Prigg v. Pennsylvania, supra, at p. 622. Justice McLean, however, did not share this doubt. He conceived that the Constitution required a positive duty of the states to surrender fugitive slaves on claim and that Congress might prescribe in what manner the claim and surrender might be made. ".... although, as a general principle, Congress cannot impose duties on state officers, yet in the cases of fugitives from labor and justice. they have the power to do so." Ibid. 665 .

${ }^{21}$ Vt. Pub. Acts, I843, no. I5.
} 
state court of record, or judge, or justice of the peace, or any other state magistrate, to take cognizance of any certificate in any case arising under the Act of I793; it forbade any executive officer of court, or any other officer, or citizen, to seize, arrest, or detain, or to aid in the seizure, arrest, or detention of any person claimed as a fugitive slave, and to transport or to aid in the transportation of such person; and it imposed as penalties a fine of one thousand dollars, or imprisonment for not more than five years. In such states the slave owner was helpless unless he was within reach of a judge of one of the federal courts. The cry went up from the slave-holding States that they were being deprived of "that solemn constitutional guaranty so sacredly pledged" at the formation of the Union and that they were now no better off than they had been under the old Confederation.

"No citizen of the South," complained the legislature of Virginia, "can pass the frontier of a non-slaveholding state and there exercise his undoubted constitutional right of seizing his fugitive slave, with a view to take him before a judicial officer and there prove his right of ownership, without imminent danger of being prosecuted criminally as a kidnapper, or being sued in a civil action for false imprisonmentimprisoned himself for want of bail, and subjected in his defence to an expense exceeding the whole value of the property claimed, or finally of being mobbed or being put to death in a street fight by insane fanatics or brutal ruffians. In short, the condition of things is, that at this day very few of the owners of fugitive slaves have the hardihood to pass the frontier of a non-slaveholding state and exercise their undoubted, adjudicated constitutional right of seizing the fugitive." 2

It was under these provocative circumstances that the bill "to amend and supplementary to, the Act of I793" was drafted, introduced into Congress, and adopted with surprisingly little debate by both Houses. ${ }^{23}$ On September I8th, I850, President Millard Fillmore set his signature to the Act which, according to Charles Sumner, earned for him eternal infamy. "Other Presidents may be forgotten; but the name signed to the Fugitive Slave Bill can never be forgotten. . . . Better far for him had he never been born; better far for his memory, and for the good name of his children, had he never been President!" With somewhat less uncharitable judgment, Mr. Rhodes wrote forty years later, "This infamous act has blighted the reputation of everyone who had any connection with it, and he has suffered with the rest." What were the provisions of this momentous legislation of 1850 ?

It should be noted at the outset that the Act of 1850 does not repeal the earlier act or any portion of it. The avowed purpose was to render

\footnotetext{
23 Va. Pub. Acts, I849-50, pp. 240-254, 248, quoted by 6 Ames, State Dociments on Federal Relations (1906) 10-12.

${ }^{23}$ An Act to anend and supplementary to, the Act entitled, "An Act respecting Fugitives from Justice and Persons escaping from the Service of their Masters." approved February twelfth, one thousand seven hundred and ninety-three. Sept I8, I850 (9 Stat. at L. 462 ).
} 
the Act of I793 adequate to the constitutional guarantees which had been given to the owners of escaped slaves. This general purpose was to be fulfilled; first, by providing effective instrumentalities for the execution of the Act; and secondly, by freeing these agents from molestation, either at the hands of private citizens or of local officials in states where reluctance to return escaped slaves overcame the sense of public obligation. The first sections of the Act, accordingly, authorize and require federal commissioners to exercise concurrent jurisdiction with the judges of the District and Circuit Courts of the United States, and to grant certificates to claimants, upon satisfactory proof, with authority to take and remove fugitives from labor to the State or Territory from which they may have fled. These commissioners are, or are to be, appointed by the Circuit Courts of the United States. Such commissioners were already authorized by the Judiciary Act of I789 to exercise the powers of any justice of the peace or other magistrate of any state by arresting, imprisoning, or bailing offenders for any crime or offence against the United States. To these original powers were now added the powers and duties conferred by the Act of $185^{\circ}$. To the superior court of each organized territory was given like power to appoint commissioners for these general and particular purposes, as need should arise.

The Act furthermore enjoined all marshals and their deputies to obey and execute all warrants directed to them and made them liable to a fine of one thousand dollars for refusal to receive or failure diligently to execute a warrant or other process issued under the provisions of the Act. If a marshal suffered a fugitive once in his custody to escape, or, if a fugitive escaped without any connivance on the part of the marshal, that officer was made liable for the full value of the service or labor of the fugitive in the State or Territory whence he had escaped. The better to execute their duties under the Constitution and the Act, the commissioners were authorized to appoint suitable persons to aid in the execution of the warrants and other processes; and they and their appointees were authorized, furthermore, to summon to their aid the bystanders or posse comitatus of the country. And all good citizens were commanded to aid in the prompt and efficient execution of the law wherever their services should be required.

The owner, or his agent, was authorized by the terms of the act to pursue and reclaim his fugitive slave either by procuring a warrant from a federal court or commissioner, or by seizing such fugitive where he could do so without process. He was then to present such person before the proper court, judge, or commissioner, whose duty it was to hear and determine the case of the claimant in a summary manner. To this court, judge, or commissioner, satisfactory proof was to be presented by the claimant; first, that he was entitled to the services or labor of the fugitive whom he sought, and secondly, that the person arrested was in fact the fugitive to whose services or labor he was 
entitled. Satisfactory proof was defined in the act as a duly authenticated transcript of the deposition or affidavit made by the claimant before any court of record in his state or territory, to the effect that a person owing him service had escaped, accompanied by a general description of the fugitive. But other and further evidence, either oral or in writing, might be required if the court, judge, or commissioner thought necessary; and in default of a transcript of a court record, the claim might be heard and determined "upon other satisfactory proofs, competent in law."

Satisfactory proof of identity having been offered, the court, judge, or commissioner was to grant a certificate setting forth the substantial facts in the case and authorizing the removal of the fugitive to the State or Territory from which he had fled. This certificate was to be held conclusive of the right of the claimant to remove his property and was to exempt him from molestation "by any process issued by any court, judge, magistrate, or other person whomsoever." Any one obstructing a claimant in arresting a fugitive or attempting to rescue a fugitive or endeavoring to conceal a fugitive, so as to prevent his discovery and arrest, was made liable to a fine not exceeding one thousand dollars and imprisonment not exceeding six months, and also liable to civil damages to the party injured by the loss of a slave by such illegal conduct.

The features which made this act so odious to men and women who abhorred human slavery strike one in the face. It seemed to them drawn with diabolical ingenuity. It was all too likely to accomplish its nefarious purpose. It closed the gap left in the Act of 1793 by the decision of Mr. Justice Story in the decision of Prigg v. Pennsylvania. Bitterly they resented those provisions which declared illegal ail humane efforts to shield the unhappy fugitive from his captors and which made slave-catchers out of bystanders when a miserable slave was attempting to elude or resist capture. Good citizens were asked to suppress all natural emotion and human pity while an unhappy fellow-being was being sent back to bondage. It may well be contended that an act which outraged the feelings of half the people of the United States was ill-advised; but the question of expediency is not here under discussion, - only the more difficult question of constitutionality.

Contemporary criticism was directed mainly_to three supposedly vulnerable points in this Act of 1850 : first, at that provision which denied to a fugitive the right to testify in his own defence; secondly, at that which provided for a summary procedure before judge or commissioner without trial by jury; and thirdly, at that provision which seemed to deny the privilege of the writ of habeas corpus. In his own vehement way Sumner summarized the case against the act as follows:

"This is the Fugitive Slave Bill-a bill which despoils the party claimed as a slave - whether he be in reality a slave or a freeman - of the sacred right of Trial by Jury, and commits the question of Human Freedom-the highest question known by law-to the unaided judgment of a single magistrate, on ex parte evidence it may be, by 
affidavits, without the 'sanction of cross-examination. Under this detestable, heaven-defying bill, not the slave only, but the colored freeman of the North, may be swept into ruthless captivity. ... In denying the Trial by Jury, it is three times unconstitutional; first, as the Constitution declares, "The right of the people to be secure in their persons against unreasonable seizures; secondly, as it further declares, that 'No person shall be deprived of life, liberty, or property without due process of law' and, thirdly, because it expressly declares, that 'In suits at common law, where the value in controversy shall exceed twenty dollars, the right of trial by jury shall be preserved.' By this triple cord did the framers of the Constitution secure the Trial by Jury in every question of Human Freedom."24

To these major articles of indictment Sumner added two others:

"These officers are appointed, not by the President with the advice of the Senate, but by the Courts of Law; they hold their places, not during good behavior, but at the will of the Court; and they receive for their services, not a regular salary, but fees in each individual case. And yet in these officers,-thus appointed and compensated, and holding their places by the most uncertain tenure-is vested a portion of that 'judicial power,' which, according to the express words of the Constitution, can be in 'Judges' only, who hold their office 'during good behavior,' who, 'at stated times, receive for their services a compensation, which shall not be diminished during their continuance in office,' and, it would seem also, who are appointed by the President and confirmed by the Senate. And, adding meanness to the violation of the Constitution, the Commissioner is bribed by a double fee, to pronounce against Freedom. If he dooms a man to slavery, he receives ten dollars; but if he saves him, his fee is five dollars. ${ }^{25}$

These charges, repeated substantially by Mr. Rhodes, ${ }^{26}$ though in less vehement language, may be considered in reverse order. To assume that the framers of the Act of. $185^{\circ}$ purposed effectively to secure the rendition of fugitive slaves by a paltry bribe of five dollars convicts Sumner and his followers of a want of humor. There may be creatures low enough in the human scale to perjure their souls for five pieces of silver, but the federal judges have not usually been held in such contempt. The fact that Charles Sumner was at this moment holding an appointment as commissioner from his friend Judge .Story should have deterred him from making so grotesque a charge. One would hesitate to dwell upon the point had it not been pressed with such insistence. The most effective retort was made by Senator Douglas to an excited and hostile audience in Chicago in the autumn of $\mathrm{r} 850$.

"All court officials who derive their compensation from fees rather than salaries," said he, "are usually paid for labor performed. There was surely nothing unreasonable or reprehensible in awarding a fee of ten dollars to a commissioner who made out a certificate for the return

\footnotetext{
${ }_{24}$ Sumner, Orations and Speeches (1850) 400-40I.

${ }^{25}$ Ibid. 402.

${ }^{28}$ I Rhodes, History of the United States from the Compromise of 7850 (I893) I85-I86.
} 
of an escaped slave and only five dollars when he simply heard the claimant and decided against him, and was thus spared the additional labor of preparing a certificate." 27

The obvious reply to Sumner's charge that the commissioners were judicial officers and therefore held their places by an unconstitutional tenure is, that they were not "judges" within the meaning of the first section of the third article of the Constitution, but inferior officers whose appointment Congress may "vest as they think proper . . . in the Courts of Law." If it be contended, however, that by virtue of the Act of I850, commissioners, while not "judges," were clothed nevertheless with judicial authority, and, therefore, should hold office by a like appointment and tenure, it may be replied that many officers have quasi-judicial duties without holding their offices by judicial tenure, such as sheriffs, county commissioners, commissioners in insolvency, and even judges of territorial courts, and in our own time members of the Interstate Commerce Commission and the Federal Trade Commission. Commissioners had been appointed by the Circuit Courts at first to take bail and affidavits in civil cases. Authority was subsequently given them to take depositions, and even to arrest and imprison for trial persons charged with offences against the laws of the United States; and yet though exercising these quasi-judicial duties, or duties ancillary to court proceedings, it had never been intimated that they should have been appointed by the President and commissioned during good behavior.

More serious is the allegation that the Act of 1850 denies, by general implication, the privilege of the writ of habeas corpus to the fugitive taken into custody. "The certificates . . . shall be conclusive of the right . . . to remove such fugitives . . . and shall prevent all molestation of such person or persons by any process issued by any court, judge, magistrate, or other person whomsoever." It was the opinion of the Attorney-General, John J. Crittenden, however, that this provision of the Act did not suspend, and was not intended to suspend, the privilege of the writ, because Congress could not suspend the privilege of the writ without a violation of the Constitution, ${ }^{28}$ and the intent to violate the Constitution ought not to be imputed to them by mere implication. The Attorney-General found no incompatibility between the Act and the privilege of the writ. The purpose of the writ is to institute an inquiry into the causes of commitment or imprisonment and to deliver the complainant from all manner of illegal confinement. The fugitive slave in custody, like all other prisoners under the laws of the

\footnotetext{
${ }^{27}$ See Allen Johnson, Stephen A. Douglas: a Study in American Politics (I908) I9I-194. In Miller v. McQuerry (1853, C. C. D. Ohio) 5 McLean, 467, 481, Judge McLean took the same view of this provision of the Act.

${ }_{23}$ "The Privilege of the Writ of Habeas Corpus shall not be suspended, unless when in Cases of Rebellion or Invasion the Public Safety may require it." U. S. Const. art. I, sec. 9 .
} 
United States, has the privilege of the writ; but whether he shall be granted the writ must depend upon the judgment of the proper tribunal. Now by the Act in question, Congress has established a tribunal or tribunals with exclusive jurisdiction to determine summarily who are fugitives from labor and to whom such labor is due. The judgment of every such tribunal of exclusive jurisdiction must be conclusive upon every other tribunal. Wherever judgment is shown upon application of the fugitive for a writ, it prevents the issuing of the writ; and if the writ has been issued, the judg'ment of the tribunal discharges the writ upon its return.

As for the last words of the sixth section of the Act-"and shall prevent all molestation," etc.-the Attorney-General assumed that they meant no more than what the Act of I793 meant by declaring that a certificate "shall be sufficient warrant for removing the said fugitive from labor."29

The constitutionality of the Act of 1850 was most insistently challenged because of its apparent conflict with the fifth and seventh articles of amendment. If no person may be deprived of life, liberty, or property without due process of law, ${ }^{30}$ and, if in suits at common law, trial by jury must be preserved, ${ }^{31}$ the summary procedure of the commissioners would seem to be in flat contradiction to the constitutional guarantee of civil liberty. This was the emphatic opinion of the Supreme Court of Wisconsin in In re Booth. ${ }^{32}$ According to Judge Smith, the presentation of a claim by the owner of a fugitive slave by legal process is the commencement of a suit, for according to the dictum of Chief Justice Marshall, a suit is the "prosecution, or pursuit of some claim, demand, or request." 33 "The trial of such a claim is the trial of a suit. Therefore the trial thereof must not only be had before a judicial tribunal, but whether proceedings be commenced by the fugitive to resist the claimant, or by the claimant to enforce, and establish his claim, it would seem that either party would be entitled to a jury.",34 To the argument that proceedings instituted to reclaim and repossess a fugitive from service did not constitute a "suit at common law" within the meaning of the Constitution, the Court replied that this question had already been judicially determined, and quoted with approval Justice Story's dictum that the seventh amendment was meant "to embrace

$\approx$ The general tenor of the Attorney-General's opinion indicates that he held the action of the commissioner to be judicial and hence not subject to review by issue of the writ of habeas corpus. It may be inferred, on the other hand, that the Attorney-General would concede the right of another tribunal to issue the writ to review the judgment of a commissioner, if such an officer was regarded as simply a ministerial or administrative agent.

${ }^{30}$ Article $\mathrm{V}$ of the amendments to the Constitution.

${ }^{31}$ Article VII, ibid.

32 . (I854) 3 Wis. I, 39.

${ }^{3}$ Cohens v. Virginia (I821, U. S.) 6 Wheat. 407.

${ }^{34}$ In re Booth, supra, at pp. 39-40. 
all suits which are not of equity or admiralty jurisdiction, whatever may be the peculiar form which they may assume to settle legal rights."35

Underlying these opinions was the assumption that the proceedings before the commissioner were not only judicial in character (hence falling under the positive injunctions of the fifth and seventh amendments) but conclusive. According to Judge Smith, who wrote the Wisconsin opinion, delivery of the fugitive by the commissioner meant that he was "reduced, without further process or trial, to absolute subjection, to be taken whithersoever the claimant may desire." In this opinion, Judge Whiton concurred:

"We are therefore obliged to conclude that the alleged fugitive from labor is taken back to the State from which he is said to have escaped, as a person who has been proved and adjudged to be a slave, and, as we believe, without due process of law, without having his rights passed upon and determined by a jury of his peers." ${ }^{\text {sB }}$

But it was precisely this underlying assumption which defenders of the Act of 1850 challenged. Were the proceedings before a commissioner judicial and therefore conclusive? Arguing the famous Robbins case in the House of Representatives, February 20, I800, John Marshall called attention to the significant fact that the Constitution declares the judicial power to extend to all cases-not questions-arising under the Constitution, treaties, and laws. ${ }^{37}$ Had the judicial power been extended to all questions, the courts might have encroached upon the functions of the executive. And in connection with claims arising under the Treaty of I8I9 with Spain, Congress had authorized a federal district judge to adjudge losses and to report his findings to the Secretary of the Treasury. In the United States v. Ferreira, ${ }^{38}$ Chief Justice Taney held that no appeal could be taken from the federal district judge to the Supreme Court.

"The decision is not the judgment of a court of justice. It is the award of a commissioner. The Act of 1834 calls it an award. . . The powers conferred by these acts of Congress, upon the judge as well as the Secretary, are, it is true, judicial in their nature. For judgment and discretion must be exercised under both of them. But it is nothing more than the power ordinarily given by law to a commissioner appointed to adjust claims to lands or money under a treaty; or special powers to inquire into or decide any other particular class of controversies in which the public or individuals may be concerned. A power of this description may constitutionally be conferred on a Secretary as well as on a commissioner. But it is not judicial in either case, in the sense in which judicial power is granted by the Constitution to the courts of the United States."

${ }^{35}$ Parsons v. Bedford (1830, U. S.) 3 Pet 433, 447; see also 2 Story, Commentaries on the Constitution (5th ed. I89r) 545-554.

${ }^{30}$ In re Booth, sipra, at p. 70.

${ }^{97} 5$ Wheat. Appendix I.

${ }^{33}$ (I851, U. S.) I3 How. 47-48. 
In line with this opinion is the decision of Judge McLean in Ex parte Robinson. ${ }^{39}$

"The nature of the duties of the Commissioners under the Act of 1850 is not, in principle, different from those which they previously discharged. . . . It must be admitted that this inquiry is somewhat in the nature of judicial power; but the same remark applies to all the officers of the accounting departments of Government. They investigate claims, and decide on the evidence. The examiners in the Patent Office determine the merits and novelty of inventions. This becomes a judicial duty in every suit between conflicting patents. It is impracticable, in carrying on the machinery of government, to prescribe precise limits to the exercise of executive and judicial power in deciding upon claims. The Supreme Court has had the acts of these Commissioners before it, and has always treated them as having authority under the law."

Much the same point of view was taken by Judge Sprague of the United States District Court of Massachusetts. A proceeding was not judicial, he contended, merely because an officer or magistrate must ascertain facts and law and act thereon in a particular case. The commissioner is to grant or withhold a certificate to carry the fugitive from service or labor from one state to another. The certificate states facts which the commissioner believes to be established; "but these facts are not thereby judicially established, but may be controverted in any future proceedings between the same parties." "What may be legally done with that person in the State to which he is carried, depends upon the laws of that State, and not upon anything in the certificate."

The suggestion thrown out by Judge Sprague is highly significant and was given full value in subsequent decisions. In the Burns case, (I854) Commissioner Loring remarked that the arrest of the fugitive is a ministerial and not a judicial act, and that the nature of the act was not altered by the means used. If extradition was the purpose of the statute and determination of the identity of the fugitive the only purpose of the proceedings under it, trial by jury was not necessary. The Constitution does not guarantee jury trial for the initial proceedings in extradition. ${ }^{41}$ In his dissenting opinion in the Booth case, Judge Crawford pursued the same fertile thought. ${ }^{42}$ To his mind there was no essential difference between the demand for a fugitive from justice and the claim of a party to whom service or labor is due.

"In either case there is a deprivation of personal liberty without the intervention of a jury, but it is considered essential to the complete enforcement and fulfilment of the constitutional compact, that a temporary deprivation should be permitted in the individual case, in order that the constitutional right may be secured. It is true, that in the case

${ }^{20}$ (1855, C. C. D. Ohio) 6 McLean, 355.

${ }^{40}$ Quoted in 2 Hurd, The Law of Freedom and Bondage (I858) 695.

${ }_{11} 7$ Monthly Law Report, 204, cited in 2 Hurd, op. cit., 677, note.

In re Booth (1854) 3 Wis. I, 83-84. 
of a fugitive from justice, he is given into the custody of the officers of justice, with the beneficent presumption of the law in favor of his innocence, until he shall have been duly convicted; while in the case of the fugitive from labor, he is placed under the control of his claimant, to be carried back to the State from which he is charged to have fled, with no presumption in favor of his freedom; but this is, I think, more an argument against the policy and justice and humanity of the law, than against its constitutionality. A case might arise where, by false swearing and conspiracy, a freeman, by the machinery of this law, might be snatched from his liberty and reduced to the condition of slavery, until, by a suitable proceeding, he asserted and obtained his freedom; but so, also by similar means, an innocent man may be carried away charged with crime, and placed under the necessity of vindicating his innocence in a distant State."

That extradition and not the final settlement of a right was the purpose of the Act of I793, and of the Act of I850 supplementary to it, seems hardly to admit of rational doubt. The fact that the Act of I793 couples the return of the fugitives from service or labor with the extradition of fugitives from justice certainly points to this conclusion. The first and second sections are devised to enable the agent appointed to recover the fugitive from justice "to transport him or her to the State or Territory from which he or she shall have fled;" the third and fourth sections declare that the certificate granted to the claimant of a fugitive from service or labor "shall be sufficient warrant for removing the said fugitive from labor to the State or Territory from which he or she fled." To this purpose the amendatory and supplementary Act of I850 adds nothing. The sixth section declares that the certificate shall be "conclusive," it is true, but "conclusive of the right to remove such fugitive": the certificate is conclusive for this purpose alone. There is nothing in either act to warrant the supposition that summary hearing is for any other purpose than extradition. And if it be said that there is not in either act any provision for further and conclusive trial for the determination of the right asserted, it may be replied that the laws of the United States do not provide for trial of the crime or offence for which the alleged fugitive from justice is extradited. ${ }^{43}$

${ }^{43}$ The parallelism between the action of governors of States in delivering up fugitives from justice and the action of commissioners in delivering up fugitives from service or labor was vigorously denied by northern writers like Hurd. (The Law of Freedom and Bondage.) It was argued that while the powers of the Commissioners were derived from the United States and could only be regarded as an extension of the judicial power, the Governors acted by virtue of their powers as chief executives of their States. Even if the States had not passed acts to enable the executive to make delivery of fugitives from justice, still the power would belong to the executive department of the State government. The quasiinternational law of the colonial period is assumed to continue between two states, which are thus made essentially one jurisdiction, the criminal law of the two being connected by the national law. (2 Hurd, op. cit., 625.) This quasi-international status was not conceded in the matter of fugitives from service and labor because 
The denial of trial by jury and of the right to testify in his own behalf applies to the fugitive from justice as well as to the fugitive from labor, and injustice may be done to perfectly innocent persons in either case. This aspect of the matter was admirably stated by Benjamin $R$. Curtis in an opinion written for the United States marshal in the Sims case: ${ }^{44}$ "If it be in the power of Congress to provide for the giving up of fugitives from justice without a trial by jury, which has been practiced on by the States for more than half a century, and never doubted, it seems to me the power is even more free from doubt in the case of a fugitive from service. Fugitives from justice may be, and often are, citizens, and under the protection of the Constitution are entitled to the benefit of its provisions; fugitives from service, when slaves, are not thus entitled. Fugitives from justice cannot be seized and carried away without some inquiry and legal process; fugitives from service may be taken anywhere, by those having a legal claim, and by force of the legal title carried from the State. If it be said that a person may be seized, and, after this summary inquiry carried away, who is not

of the difference between state laws relating to freedom and bondage and because "the delivery of a person accused of crime is a preliminary proceeding in reference to a prospective exercise of judicial power." This latter reason, it will be observed, rests upon the assumption which the author is trying to prove and is thus worthless. It has yet to be shown that the action of a commissioner was not prospective to the final determination of facts in the State from which the fugitive had fled. Another curious argument which Hurd stated with approval rests on no better foundation. The action of the commissioner is final and the action of the governor ancillary because by the terms of the Constitution the fugitive from justice is to be delivered up, "to be removed to the State having jurisdiction of the crime" while the Constitution is silent as to the fugitive from service or labor, simply stating that he "shall be delivered up on claim of the party to whom such service or labor may be due." Nothing would therefore prevent the claimant from removing his alleged slave to another state than that in which he resided or from simply holding his property in the State where the fugitive had been apprehended, if that were a slave-holding state. In this case, asks Hurd, triumphantly, what becomes of the trial of facts? How could the master be forced to return to his own State for the final ascertainment of his right to the alleged slave? Had Congress, however, provided for the slave's continuing in national public custody in transitu until the claim was finally determined, then the chief constitutional objections to the act would have been removed. (2 Hurd, op. cit., 696.) "Then there would be a real parallelism between the removal under the Commissioners' action and an extradition in the case of a fugitive from justice." But it may be replied that no such assurance is given that a state agent who receives the alleged criminal will deliver him up for trial. The agent is a state, not a national officer. Why could he not also elude final trial by leaving the country with his prisoner if he were bent on kidnapping him for some nefarious purpose? A defect or defects in the Act of 1850 cannot be pleaded as a reason for declaring unconstitutional the powers actually conferred. Congress might properly be censured for its want of foresight in providing for all possible contingencies, but the courts would hesitate on this account to declare void the positive means taken to reach an end sanctioned by the Constiitution, if they were well within the purview of that document.

14 (I851, Mass.) 7 Cush. 285. 
a fugitive from service, and thus a citizen may be temporarily, and perhaps finally, deprived of his liberty, because he may not find means to defend himself where he is carried; it may be said also that a person may be carried away, who is not a fugitive from justice, and may be unjustly and oppressively dealt with in the place to which he is transported. The truth is, the Constitution has in view neither of these cases. It provides great general rules and powers, leaving to legislation to guard and limit the practical application of those powers so that injustice shall not be done; and if opportunity is given for injustice, it is the fault of the Legislature who have not wisely exercised their powers, but by no means proves that the action of the Legislature exceeds its powers."

To Northern men and women living in the heated atmosphere of the slavery controversy, this way of reasoning seemed inconclusive. They had full confidence that the fugitive from justice would receive fair trial in the State from which he had fled; they did not feel the need of throwing safeguards around the summary process which preceded his rendition; they acquiesced, therefore, in the unquestioned practice of half a century. But they regarded the argument of analogy from the law concerning the rendition of fugitives from justice as altogether specious. Who really believed that when a master had a negro in his possession he would present him for trial in the courts of his own State, or that the officials of these courts would be punctilious in settling the question of right when a master returned with a negro and the certificate of a commissioner? The Northern mind clung to the prepossession that the negro slave had no chance to win his freedom in courts which were controlled by the slave-holding class. To this type of mind, a merely legal argument made slight appeal. Where was the evidence that the unhappy fugitive slave would receive even the semblance of a trial when extradited to the State from which he had fled?

While the Fugitive Slave Bill was under discussion in the summer of I850, repeated efforts were made in Congress to secure consideration of amendments which would guarantee a fair trial to the fugitive in the State by whose laws he was said to be held to service or labor. One amendment proposed that in case the alleged slave should dispute the findings of the commissioner or judge and claim his freedom, the owner should give the commissioner or judge bond that he would take him to the court of the county in which he resided and there allow a trial of the facts by jury. ${ }^{45}$ Another amendment-in effect a substitute for the original bill-provided for a trial in the State to which the reclaimed fugitive should be taken, which trial was "to be conformable to the laws of the State in that behalf. ${ }^{46}$

(I850) 22 (part I) Congressional Globe, Ist Sess., 3Ist Cong., App. 57 I.

"Ibid. 
The first of these amendments was supported by Henry Clay in the Senate not as a matter of justice to the escaped slave, but as a concession to Northern sentiment.

"It is granting to the slave," said he, "only the right which he now indisputably possesses, in all the slave-holding States, of resorting to their tribunals of justice to establish his claim to freedom if he has one."

Testifying to facts within his own experience, Clay said further:

"I have never known an instance of a failure on the part of a person thus suing to procure a verdict and judgment in his favor, if there were even slight grounds in support of his claims."

Senator Underwood of Kentucky, who urged the second amendment, endorsed all that his colleague had said.

"In my section of the country and in all the Southern States, if a man is held in custody as a slave, and can find a lawyer and present anything like a plausible case for freedom, his situation will at once induce that lawyer to institute a suit without fee or reward; and in my section of the country, the laws give a man thus circumstanced an opportunity of prosecuting his claim in forma pauperis ... In fact, it is a matter of professional pride that every man shall have his case properly investigated and fairly adjudicated upon." 48

Senator Underwood agreed with Clay, also, in thinking that an amendment providing for trial of the facts in the State from which the fugitive had escaped, however unnecessary from his point of view, was a wise concession to public feeling in the North. If such a provision was not made, he feared that the North would insist that inquiry into the facts and trial should be held in the State where the fugitive should be apprehended. "Trial abroad," he declared, bluntly, "is ruinous to us."

But Senator Mason of Virginia, the reputed author of the bill, and the intransigeant Senators who followed his lead, turned a deaf ear to all pleas for concession. All amendments were rejected, largely, it would seem, because the rights of the fugitive were believed to be amply safeguarded in the slave-holding States, ${ }^{49}$ and because the slow procedure necessitated by jury trial was a costly matter to the planter. Addressing the Senate on this subject, Jefferson Davis of Mississippi declared that "the right of jury trial, if there be any question as to the condition of a person of color in regard to freedom or slavery, already exists

4 Ibid. 612.

${ }^{48}$ Ibid. 572 .

60 "In my own state, and I doubt not in the State of Kentucky, and every other slave State, they [slaves] are not only entitled to be heard, but the law requires the master, on a prima facie case being made out, to give a bond and security that the slave shall not be removed until the case is decided. It allows him to sue in forma panperis, without costs, provides for his safety while the suit is pending, and provides that he shall have full liberty to consult with counsel, summon witnesses, and prepare for trial." Aug. 22, I850. (part 2) Ibid. I6rI. 
in every slave-holding state. ${ }^{50}$ Such assurances, coming from Southern leaders who were thoroughly distrusted as mere mouth-pieces of the slave-owning barons, carried no conviction to Northern minds; and an extended search through local court records has yet to be made before they can be thoroughly substantiated. From a cursory examination of the session laws of the border slave States, from which most of the slaves escaped, the writer is persuaded that substantial justice was on the whole accorded to the negro claiming his freedom..$^{51}$ It is not clear, however, that in suits for freedom, jury trial was either necessary or usual..$^{52}$ The negro suing for his freedom was usually allowed counsel and could have his master and witnesses subpœnaed. Further to protect the petitioner, the master might be required to give bonds to present him at court on the date set for hearing or trial.

It has already been remarked that contemporary criticism of the Act of $185^{\circ}$ proceeded from the assumption that because the duties of commissioners were quasi-judicial, the powers conferred by act of Congress were derived from the third article of the Constitution. In other words, the Act of 1850 was constitutional only if considered as an extension of the judicial power of the United States. From this point of view the powers of the commissioners would be subject to all the limitations in the Constitution which hedged about the judiciary. As administrative agents for purposes of extradition, on the other hand, the commissioners would exercise wide powers affecting liberty and property without being circumscribed by the restrictions imposed by the Constitution upon the judiciary. The rapid development of administrative boards and agents in the last half century throws a new light on the determinations left to the commissioners by the Act of 1850 . Such boards and officers frequently exercise powers which are judicial in their nature and reach conclusions which affect property rights; yet these determinations are now held to constitute "due process of law" and are conclusive. The Supreme Court has said in unmistakable language ${ }^{53}$ that "there are matters, involving public rights, which may be presented in such form that the judicial power is capable of acting on them, and which are susceptible of judicial determination, but which Congress may or may not bring within the cognizance of the courts of the United States, as it may deem proper." "It is true, also, that even in a suit between private persons to try a question of private rights, the

\footnotetext{
${ }^{s 0}$ Ibid. 1588 .
}

" See, for example, the Act of Missouri "to enable persons held in slavery to sue for their freedom." Rev. Sts. 1856, ch. 69.

${ }^{5}$ A Delaware law of 1852 provided that "the court shall hear proofs in a summary way and upon satisfactory evidence that the petitioner is entitled to his freedom, shall adjudge and decree accordingly, and shall discharge him from his master's custody." Rev. Sts. I852, ch. 80. A thorough-going investigation of the laws and court procedure relating to slaves is greatly needed.

${ }^{*}$ Murray's Lessee v. Hoboken, etc. Co. (I855, U. S.) I8 How. 272-284. 
action of the executive power, upon a matter committed to its determination by the constitution and laws, is conclusive." The authority conferred upon the Postmaster-General to exclude from the mails matter tending to encourage crime and immorality or fraudulent matter, is a power which may vitally affect private business. It is judicial in character, for determinations are reached after inquiry and hearings. The essence of a judicial inquiry, Mr. Justice Holmes has said, is that it "investigates, declares and enforces liabilities as they stand on present and past facts and under laws supposed already to exist." The powers conferred upon the Interstate Commerce Commission furnish another instance of judicial powers conferred upon an administrative board. Yet the determinations of the Commission reached without jury trial and affecting vast property interests are held to conform to due process of law. Even more striking and pertinent to the subject of this paper is the authority conferred by the federal laws regulating immigration upon the Department of Labor. To boards of immigrant inspectors, subject to appeal to the Secretary of Labor, belongs the decision of cases involving no less a matter than American citizenship. Chinese, born in the United States and subject to its jurisdiction, are citizens by the terms of the Fourteenth A.mendment. Yet should such a citizen have the temerity to leave the country and then seek re-entrance, his constitutional rights would be determined by the immigration board without trial by jury. He becomes subject to the exclusive provisions of our immigration laws, according to the ruling of the Supreme Court. $^{55}$

The people of the United States have travelled far on the road to government by administrative commissions since the middle of the last century. So long as they acquiesce in the extraordinary determinations reached by administrative boards regarding rights of citizenship, they are likely to look with less and less passion upon the controversy which culminated in the assault upon the constitutionality of the Fugitive Slave Acts. Measured by the developments of a half-century and interpreted in the light of reason, these acts must be declared constitutional in every particular.

\footnotetext{
${ }^{54}$ Prentis v. Atlantic Coast Line (1908) 2rI U. S. 210, 226, 29 Sup. Ct. 67, 69. Cited by Charles W. Needham, Judicial Determinations by Administrative Commissions (IgI6) Io AMrer. Pol. Scr. Rev. 235, 236.

" ${ }^{85}$ Lewis v. Frick (I914) 233 U. S. 29I, 34 Sup. Ct. 488 ; Ueberall v. Willians (IgI I, S. D. N. Y.) I87 Fed. 470. Cited by Louis F. Post, Adninistrative Deci sions in Comection with Immigration (I9I6) ro AMre. PoL. Scr. REv. 25I, 254.
} 